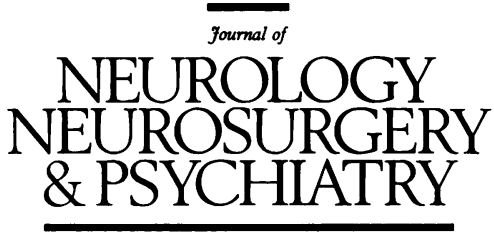

\title{
Editorial
}

\section{The basis for behavioural disturbances in dementia}

Although behavioural disturbances in demented people are a prominent part of their disease it is only in recent years that attempts have been made to understand the changes in the brain that account for such disturbances. For this type of research to be carried out the behavioural changes themselves need first to be defined and regularly observed over a long period in a large number of patients who eventually undergo postmortem examination. This is no easy task, particularly now that demented patients are largely cared for outside hospitals. It is therefore perhaps not surprising that progress has been slow. However, it is important to undertake such research as it may yield results that point the way to effective remedies for what are the most intractable, disruptive, and distressing aspects of dementia for many carers.

Rating scales for behaviour in general psychiatric populations are not well suited for use in dementia, but there have now been several studies of behaviour in dementia that have led to the development of rating instruments for its assessment. ${ }^{1}$ Such studies have begun the task of documenting the frequency and natural history of behaviourial abnormalities in dementia. These abnormalities are conveniently considered under four headings: depressive, psychotic, anxiety related, and activity associated. Depressive behavioural disturbances include apathy, withdrawal, listlessness, tearfulness, and other manifestations of unhappiness. Psychotic abnormalities are expressed as hallucinations, paranoia, and delusions. Activity associated abnormalities are very varied but include wandering, agitation, restlessness, eating and sexual disorders, aggression, sleep disturbances, rummaging, and hoarding. Some investigators prefer to confine a definition of behaviour in dementia to observable acts, which would exclude delusions, hallucinations, and mood disorders. ${ }^{2}$

Surveys of the frequency with which these conditions are seen in demented patients have produced surprisingly varied results, ${ }^{1}$ probably because of different definitions used, patient groups studied, and methods of assessment. However, most studies are in agreement that behavioural abnormalities are common in dementia. Because many demented patients have difficulty in understanding and expressing themselves the basis for assessment is best provided by directly observable behaviour documented by a close and reliable witness with a well validated rating instrument. ${ }^{13}$

Although some odd or irrational behaviour in dementia may be directly linked to cognitive impairment, leading to misunderstanding or misinterpretation of events or peo- ple, most behavioural change in dementia is not thought to be solely a consequence of cognitive impairment. Some altered behaviour may be manifested before there is much change in cognition and may be the presenting feature, indicating a high risk for subsequent development of dementia. ${ }^{4-7}$ Therefore, it is appropriate to search for an underlying pathological and neurochemical substrate for these behavioural abnormalities independent of those that underlie cognitive impairment. In searching for such a substrate there are good reasons for concentrating attention on the noradrenalin and serotonin (5-HT) neurotransmitter systems that project from subcortical nuclei to the cortex. Firstly, there are many animal studies in which these systems have been lesioned and behaviour profoundly altered as a consequence. ${ }^{8}$ Secondly, these systems are known to be affected pathologically in Alzheimer's disease, and in some other dementing diseases. Thirdly, drugs acting on these neurotransmitter systems are known to influence behaviour both in humans and animals. ${ }^{9}$ Studies relating noradrenalin and 5-HT to behavioural changes in dementia are reviewed below. Other sites of pathology are also worthy of consideration on the basis of animal lesioning studies-for example, the amygdala and hypothalamus. However, these areas have as yet hardly begun to be explored in relation to behaviour in dementia and will not be considered here.

Several types of study relating noradrenalin and 5-HT to behavioural disturbances in dementia have been undertaken. Thus there are studies of neurotransmitters and their metabolites in CSF in live subjects and in CSF and brain postmortem. Postmortem studies have involved neuronal cell counts and structural markers of pathology such as neurofibrillary tangles in Alzheimer's disease in various nuclei as well as neurochemical studies of neurotransmitters and their reuptake sites (as markers of presynaptic endings) and postsynaptic receptors in brain tissue. Most studies have been performed on patients with Alzheimer's disease or Lewy body disease. As with clinicopathological studies of cognitive impairments, the most reliable studies are those in which regular, systematic, prospective evaluation of behavioural disease features were made. A further important consideration, particularly in neurochemical studies, is the medication that patients received.

\section{Noradrenalin}

The major source of noradrenalin in the brain is the locus coeruleus in the pons, in which neuronal loss in 
Alzheimer's disease, and either shrinkage or loss in Parkinson's disease, is well documented. ${ }^{10-16}$ Four studies have linked cell loss and other pathological changes in the locus coeruleus with depressive symptoms and signs, retrospectively assessed, in Alzheimer's disease. ${ }^{17-20}$ Despite substantial neuronal loss in the locus coeruleus in Alzheimer's disease, markers of noradrenalin metabolism in brain tissue or CSF are either unchanged or increased, suggesting that increased turnover in surviving presynaptic endings compensates to some extent for the cell loss, although it may be insufficient to maintain normal noradrenalin concentration at all times. ${ }^{21-28}$ In non-depressed patients with Alzheimer's disease normal or raised noradrenalin and metabolite concentrations were found in $\mathrm{CSF},{ }^{29-31}$ with a tendency for concentrations to rise with increasing severity of disease. There have been no studies directly linking neurochemical changes in noradrenalin status with behavioural changes in Alzheimer's disease. A study of the response of patients with Alzheimer's disease to $\alpha-2$ adrenergic receptor blockade suggested that the increase in adrenalin in CSF that this provoked was exaggerated in elderly subjects and patients with Alzheimer's disease compared with young subjects, and led to the development of agitation and psychotic symptoms in patients with Alzheimer's disease. ${ }^{32}$ The compensatory response to disturbances in noradrenalin transmission in Alzheimer's disease seems to include an increase in cortical $\beta-2$ adrenergic receptors ${ }^{33}$ and it is noteworthy that propranolol, a $\beta$-adrenergic receptor antagonist reduces disruptive or agitated behaviour in Alzheimer's disease and other dementias. ${ }^{34-36}$ Thus impaired noradrenalin production may be associated with depression and overcompensation may induce agitation and psychotic or disruptive behaviour.

\section{Serotonin (5-HT)}

The sources of brain 5-HT are the raphe nuclei in the upper brain stem. Neuronal loss in the dorsal raphe, as in the locus coeruleus, is well established in Alzheimer's disease. $^{37-40}$
In a prospective behavioural study, the extent of neuronal loss in the raphe nuclei was unrelated to behavioural disturbances in Alzheimer's disease. ${ }^{41}$ However, studies of presynaptic 5-HT endings and postsynaptic 5-HT receptors have disclosed complex alterations in Alzheimer's disease, some of which have been linked to behavioural disturbances. Earlier studies based largely on institutionalised patients, many of whom were probably on neuroleptic medication, showed deficiencies of cortical 5-HT in Alzheimer's disease. ${ }^{42}{ }^{43} \mathrm{~A}$ more recent study that took account of medication showed no significant reduction (compared with age matched controls) in cortical 5-HT in patients with Alzheimer's disease prospectively assessed for behavioural abnormalities. However, there was increased turnover of 5-HT as reflected in increased ratios of the 5-HT metabolite 5-hydroxyindoleacetic acid to 5HT. ${ }^{44}$ Whereas in the control subjects and in unmedicated patients with Alzheimer's disease the concentration of cortical 5-HT was in the normal range and unrelated to neuronal counts in the dorsal raphe. In patients with Alzheimer's disease on neuroleptic medication the mean cortical 5-HT concentration was reduced and the concentration correlated with the extent of neuronal loss in the dorsal raphe. This suggests that in the absence of neuroleptic drugs there are compensatory changes in presynaptic terminals that make good any deficiency of 5-HT that would otherwise result from neuronal loss in the dorsal raphe and that these compensatory changes are interfered with by neuroleptic drugs. Furthermore, reduced paroxetine binding, a measure of 5-HT reuptake sites on presynaptic terminals, was correlated with features of depression. ${ }^{44}$ The cortical postsynaptic $5-\mathrm{HT}_{1 \mathrm{~A}}$ receptor (thought to be located on pyramidal neurons) was unchanged in density, as measured by 8 -hydroxy-2-[di-Npropylamino] tetralin (8-OH-DPAT) binding. The $5-\mathrm{HT}_{2 \mathrm{~A}}$ receptor (thought to be located on pyramidal neurons and interneurons) ${ }^{45}$ measured by ketanserin binding, was reduced except in anxious patients with Alzheimer's disease, in whom it was maintained. ${ }^{46}$ These studies on cortical markers of 5-HT metabolism in relation to behavioural changes suggest that anxious patients with

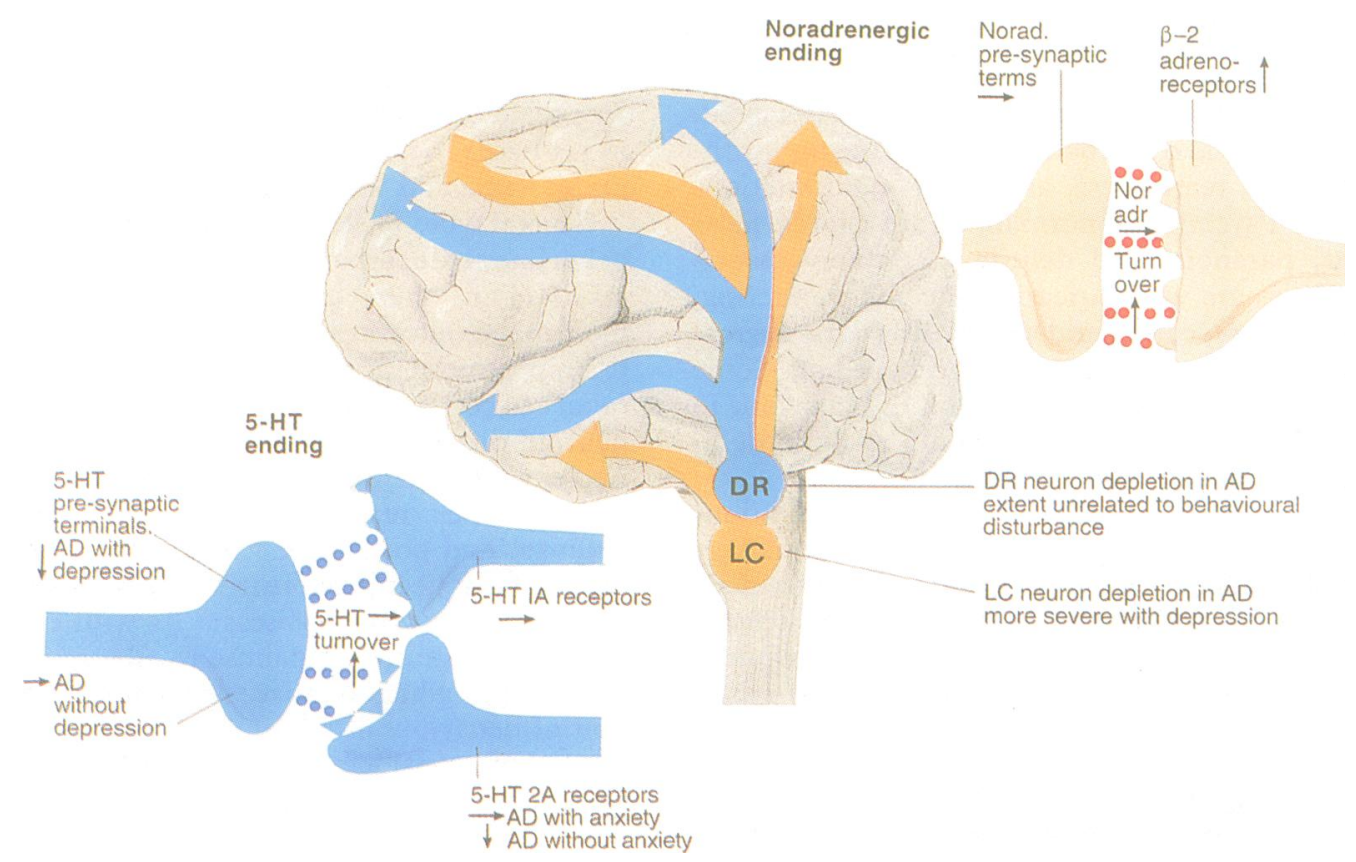

Alterations in 5-HT and noradrenalin neurotransmission in Alzheimer's disease described in the text. Alterations that have been correlated with behavioural disturbances are indicated by shading. $\leftarrow$ And $\rightarrow=$ no change; $\downarrow=$ decrease; $\uparrow=$ increase; $D R=$ dorsal raphe nucleus; $L C=$ locus coeruleus; pre-syn terms = pre-synaptic terminals;

5-HT = serotonin; Noradr $=$ noradrenalin; $A D=$ Alzheimer's disease . 
Alzheimer's disease might benefit from a $5-\mathrm{HT}_{2 \mathrm{~A}}$ receptor blocker and that depressed patients with Alzheimer's disease may be helped by blockers of 5-HT reuptake sites. The finding that neuroleptic drugs interfere with compensatory responses in the 5-HT system cautions against their use in patients with dementia as do independent findings that neuroleptic drugs hasten cognitive decline in Lewy body disease $\mathrm{e}^{47} 48$ and accelerate neurofibrillary change. ${ }^{49}$

\section{Relations between altered noradrenergic, serotonergic, and cholinergic transmission}

A reduction in cortical cholinergic transmission in Alzheimer's disease and Lewy body disease has long been recognised and is brought about by shrinkage and depletion of neurons in the basal nucleus of Meynert. ${ }^{50-54}$ This reduction in cholinergic transmission is correlated with the severity of cognitive impairment in Alzheimer type diseases. ${ }^{556}$ In some studies neuronal loss in the nucleus basalis or measures of cholinergic transmission in the cortex have been correlated with behavioural disturbances in Alzheimer's disease or Lewy body disease. Thus neuron numbers and neocortical choline acetyl transferase in the basal nucleus were lower in hallucinating than in nonhallucinating patients with Lewy body disease, ${ }^{54} 57$ and Förstl et $a^{20}$ found a correlation between nucleus basalis neurons and depression, the cells being preserved in depression.

\section{Conclusions}

Recent studies identifying neurochemical and pathological correlates of behavioural change in dementia (figure) offer the prospect that specific behavioural changes can indeed be explained in terms of specific imbalances in neurotransmission. These come about in part through damage to the subcortical nuclei affected by disease and in part through inadequate or excessive compensatory responses, some of which may be influenced adversely by injudicious medication. Further progress in understanding the complex mechanisms involved is likely to lead to improved control of distressing behavioural manifestations in dementia.

I am grateful for critical reading of this manuscript to Drs C P L Chen, P T Francis, T Hope, and R McShane.

Departments of Neuropathology and Neurology,

MARGARET M ESIR

Radcliffe Infirmary, Oxford

Correspondence to: Dr M M Esiri.

1 Patterson MB, Bolger JP. Assessment of behavioural symptoms in Alzheimer's disease. Alzheimer Dis Assoc Disord 1994;8(suppl 3):4-20.

2 Hope T, Patel V. Assessment of behavioural phenomena in dementia. In Burns A, ed. Ageing and dementia: a methodological approach. London: Arnold, 1993:221-36.

3 Hope T, Fairburn CG. The present behavioural examination (PBE): the development of an interview to measure current behavioural abnormalities. Psychol Med 1992;22:223-30.

$4 \mathrm{Kral}$ VA. The relationship between senile dementia (Alzheimer type) and depression. Can $\mathcal{F}$ Psychiatry 1983;28:304-6.

5 Reding M, Haycox J, Blass J. Depression in patients referred to a dementia clinic: a three-year prospective study. Arch Neurol 1985;42:894-6.

6 Alexopoulos GS, Abrams RC, Young RC, et al. Cornell scale for depression in dementia. Biol Psychiatry 1988;23:271-84.

$7 \mathrm{Kral}$ VA, Emery OB. Long-term follow-up of depressive pseudodementi of the aged. Can $\mathcal{F}$ Psychiatry 1989;34:445-6.

8 Foote SL, Bloom FE, Aston-Jones G. Nucleus locus ceruleus: new evidence of anatomical and physiological specificity. Physiol Rev 1983; 63:844-914.

9 Glennon RA. Serotonin receptors: clinical implications. Neurosci Biobehav $\operatorname{Rev} 1$ 1990;14:35-47.

10 Mann DMA. The locus coeruleus and its possible role in ageing and degenerative disease of the human central nervous system. Mech Aging Dev 1983;23:73-94.

11 Tomlinson BE, Irving D, Blessed G. Cell loss in the locus coeruleus in senile dementia of Alzheimer type. 7 Neurol Sci 1981;49:419-28.

12 Bondareff W, Mountioy CQ Roth M. Loss of neurons of origin of the adrenergic projection to cerebral cortex (nucleus locus coeruleus) in senile dementia. Neurology 1982;32:164-8.
13 Iversen LL, Rossor MN, Reynolds GP, et al. Loss of pigmented dopamine$\beta$-hydroxylase positive cells from locus coeruleus in senile dementia of $\beta$-hydroxylase positive cells from locus coerule

14 Chui HC, Mortimer JA, Slager U, Zarow C, Bondareff W, Webster DD. Pathologic correlates of dementia in Parkinson's disease. Arch Neurol 1986;43:991-5.

15 Marcyniuk B, Mann DMA, Yates PO. The topography of cell loss from locus coeruleus in Alzheimer's disease. F Neurol Sci 1986;76:335-45.

16 Zweig RM, Cardillo JE, Cohen M, Giere S, Hedreen JC. The locus coeruleus and dementia in Parkinson's disease. Neurol 1993;43:986-91.

17 Zweig RM, Ross CA, Hedreen JC, et al. The neuropathology of aminergic nuclei in Alzheimer's disease. Ann Neurol 1988;24:233-42.

18 Zubenko GS, Moossy J. Major depression in primary dementia: clinical and neuropathologic correlates. Arch Neurol 1988;45:1182-6.

19 Chan-Palay V, Asan E. Alterations in catecholamine neurons of the locus coeruleus in senile dementia of the Alzheimer type and in Parkinson's disease with and without dementia and depression. $f$ Comp Neurol disease with and

20 Förstl H, Burns A, Luthert P, Cairns N, Lantos P, Levy R. Clinical and neuropatholo Med 1992;22:877-84

21 Winblad B, Adolfsson R, Carlsson A, Gottfries CG. Biogenic amines in brains of patients with Alzheimer's disease. In: Corkin S, ed. Alzheimer' disease: a report of progress. New York: Raven Press, 1982:25-33.

22 Francis PT, Palmer AM, Sims NR, et al. Neurochemical studies of earlyonset Alzheimer's disease. N Engl $\mathcal{F}$ Med 1985;313:7-11.

23 Palmer AM, Francis PT, Bowen DM, et al. Catecholaminergic neurones assessed antemortem in Alzheimer's disease. Brain Res 1987;414:365-75.

24 Palmer AM, Wilcock GM, Esiri MM, Francis PT, Bowen DM. Monoaminergic innervation of the frontal and temporal lobe in Alzheimer's disease. Brain Res 1987;401:231-8.

25 D'Amato RJ, Zweig RM, Whitehouse PJ, et al. Aminergic systems in Alzheimer's disease and Parkinson's disease. Ann Neurol 1987;22: 229-36.

26 Carlsson A. Brain neurotransmitters in aging and dementia: similar changes across diagnostic dementia groups. Gerontology 1987;33:159-67.

27 Murray MA, Peskind ER. Neurobiologic bases of noncognitive behavioral problems in Alzheimer's disease. Alzheimer Dis Assoc Disord 1994;8 (suppl 3)54-60

28 Adolfsson R, Gottfries CG, Roos BE, Winblad B. Changes in the brain catecholamines in patients with dementia of Alzheimer type. Br $\mathcal{F}$ Psychiatry 1979;135:216-23.

29 Raskind MA, Peskind ER, Hatter JB, Jimerson DC. Norepinephrine and MHPG levels in CSF and plasma in Alzheimer's disease. Arch Gen Psychiatry 1984;4:343-6.

30 Palmer AM, Sims NR, Bowen DM, et al. Monoamine metabolite concentrations in lumbar cerebrospinal fluid of patients with histologically verified Alzheimer's dementia. $\mathcal{F}$ Neurol Neurosurg Psychiatry 1984;47:481-4.

31 Gibson CJ, Logue M, Growdon JH. CSF monoamine metabolite levels in Alzheimer's and Parkinson's disease. Arch Neurol 1985;42:489-92.

32 Raskind MA, Peskind ER, Wingerson D, Pascualy M, Dobie DJ, Veith RC. Enhanced cerebrospinal fluid norepinephrine response to yohimbine in aging and Alzheimer's disease. Soc Neurosci Abs 1993;19:400.

33 Kalaria RN, Andom AC, Tabaton M, Whitehouse PJ, Harik SI, Unnerstall JR. Adrenergic receptors in aging and Alzheimer's disease: increased $\beta 2$ receptors in prefrontal cortex and hippocampus. $f$ Neurochem 1989; 53:1772-81.

34 Yudofsky S. Propranolol in the treatment of rage and violent behaviour in patients with chronic brain syndrome. Am $\mathcal{F}$ Psychiatry 1981;138:218-30. patients with chronic brain syndrome. Am $\mathcal{f}$ Psychiatry 1981;138:218-30.
Petrie WM, Ban TA. Propranolol in organic agitation. Lancet 1987;324: 327.

36 Weiler PG, Mungas D, Bernick C. Propranolol for the control of disruptive behaviour in senile dementia. F Geriatr Psychiatry Neurol 1988;1:226-30.

37 Mann DMA, Yates PO. Serotonin nerve cells in Alzheimer's disease. $f$ Neurol Neurosurg Psychiatry 1983;46:96-8.

38 Yamamoto T, Hirano A. Nucleus raphe dorsalis in Alzheimer's disease: neurofibrillary tangles and loss of large neurons. Ann Neurol 1985;17: 573-7.

39 Halliday GM, McCann HL, Pamphlett R, et al. Brainstem serotonin-synthesising neurons in Alzheimer's disease: a clinicopathological correlation. Acta Neuropathol 1992;84:638-50.

40 Aletrino MA, Vogels DJM, Van Doinburg PHMF, Ten Donkelaar HJ. Cell loss in the nucleus raphe dorsalis in Alzheimer's disease. Neurobiol Aging 1992;13:461-8.

41 Chen CP, Eastwood SL, McDonald B, Hope RA, Cotton RG, Esiri MM Patterns and markers of cell loss in the dorsal raphe nucleus in Alzheimer's disease. Neuropathol Appl Neurobiol 1994;20:503.

42 Arai $\mathrm{H}$, Kosaka K, lizuka R. Changes in biogenic amines and their metabolites in post mortem brains from patients with Alzheimer-type dementia. $\mathcal{J}$ Neurochem 1984;43:388-93.

43 Palmer AM, Francis PT, Benton JS, et al. Presynaptic serotonergic dysfunction in patients with Alzheimer's disease. F Neurochem 1987;48: $8-15$

44 Chen CPL-H, Alder JT, Bowen DM, et al. Presynaptic serotonergic markers in community-acquired cases of Alzheimer's disease: correlations with depression and neuroleptic medication. F Neurochem 1996;66:1592-8.

45 Burnet PJW, Eastwood SL, Lacey K, Harrison PJ. The distribution of $5-\mathrm{HT}_{1 \mathrm{~A}}$ and $5-\mathrm{HT}_{2 \mathrm{~A}}$ receptor $\mathrm{mRNA}$ in human brain. Brain Res 1995;676:157-68.

46 Chen CPL-H, Hope RA, Alder JT, et al. Loss of $5 \mathrm{HTT}_{2 \mathrm{~A}}$ receptors in Alzheimer's disease neocortex is associated with cognitive decline whilst preservation of $5 \mathrm{HT}_{2 \mathrm{~A}}$ receptors is associated with anxiety. Ann Neurol 1994;36:308-9.

47 McKeith I, Fairbairn A, Perry R, Thompson P, Perry E. Neuroleptic sensiivity in patients with senile dementia of Lewy body type. $B M F 1992$; 305:673-8.

48 McShane R, Hope $T$, Jacoby $R$. The impact of neuroleptic medication on cognitive decline in dementia. Neurobiol aging 1996 (in press).

49 Wisniewski HM, Constantinidis J, Wegiel J, Bobinski M, Tarnawski M. Neurofibrillary pathology in brains of elderly schizophrenics treated with neuroleptics. Alzheimer Dis Assoc Disord 1994;8:211-27.

50 Whitehouse PJ, Price DL, Struble RG, et al. Alzheimer disease and senile dementia: loss of neurons in the basal forebrain. Science 1982;215: 1237-9.

51 Coyle JT, Price DL, Dehong MR. Alzheimer's disease: a disorder of cortical cholinergic innervation. Science 1983;219:1184-90. 
52 Davies P, Maloney AT. Selective loss of central cholinergic neurons in Alzheimer's disease. Lancet 1976;ii:1403.

53 Bowen DM, Smith CB, White P, Davison AN. Neurotransmitter related enzymes and indices of hypoxia in senile dementia and other abiotrophies. Brain 1976:99:459-96.

54 Perry EK, Irving D, Kerwin J, et al. Cholinergic transmitter and neurotrophic activities in Lewy body dementia: similarity to Parkinson's and distinction from Alzheimer's disease. Alzheimer Dis Assoc Disord 1993, 7:69-79.
55 Perry EK, Tomlinson BE, Blessed G, et al. Correlation of cholinergic abnormalities with senile plaques and mental test scores in dementia. aMF 1978;ii:1457-9.

56 Wilcock GK, Esiri MM, Bowen DM, Smith CCT. Alzheimer's disease: correlation of cortical choline acetyltransferase activity with severity of correlation of cortical choline acetyltransferase activity with severity

57 Perry EK, Marshall E, Thompson P, et al. Monoaminergic activities in Lewy body dementia: relation to hallucinosis and extra pyramidal features. $\mathcal{F}$ Neural Transm Park Dis Dement Sect 1993;6:167-77.

\section{NEUROLOGICAL STAMP}

\section{Joseph Hyrtl (1811-94)}

Joseph Hyrtl's father was a musician in the famous orchestra of Count Esterhazy and Hyrtl himself was a chorister in his boyhood. He preferred medicine to music, and entered the University of Vienna to graduate in 1835 and was one of the founders of the new Vienna School. His interests centred on anatomy. At the age of 26 he became professor of anatomy in Prague and then in 1844 when aged 33, professor of anatomy in Vienna where he occupied the chair for 30 years. He became famous as a teacher and historian and was one of the exceptional medical leaders in Vienna. Hyrtl was one of the world's leaders in descriptive anatomy and his Lehrbuch (1846) was the German equivalent of Gray's Anatomy. There were 22 editions and it was translated into most languages. He did not add illustrations until the 20th edition. The textbook held its appeal because of its lucid style and clear descriptions. As a teacher and instructor he was widely admired. Hyrtl was especially devoted to osteology and possessed a wonderful collection of skeletons, both animal and human. He also developed the technique for making "corrosive preparations", in which the blood vessels of an organ were injected and the other tissues dissolved away by acid leaving the vasculature clearly seen. $\mathrm{He}$ studied the anatomy of the inner ear of humans and animals, described an anastomotic loop between the right and left hypoglossal nerves in the geniohyoid and an incomplete band of circular muscle fibres in the rectum. He was honoured philatelically by Austria in the famous series published in 1937 portraying Austrian doctors (Stanley Gibbons 821, Scott B162).

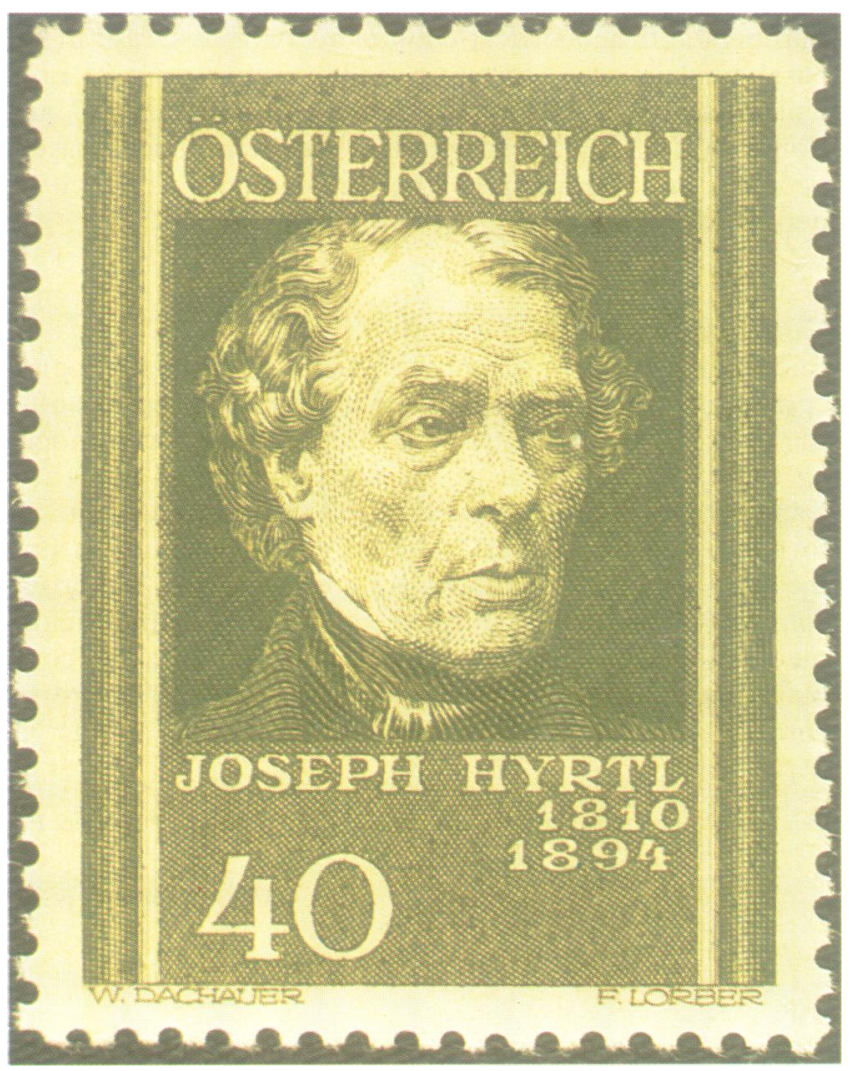

